\title{
XCIII. On the laws observed in the distribution of vegetable forms
}

\section{Count Alexander Humboldt}

To cite this article: Count Alexander Humboldt (1816) XCIII. On the laws observed in the distribution of vegetable forms, Philosophical Magazine Series 1, 47:218, 446-453, DOI: $10.1080 / 14786441608628504$

To link to this article: http://dx.doi.org/10.1080/14786441608628504

里 Published online: 27 Jul 2009.

Submit your article to this journal $\sqsubset \pi$

Џll Article views: 6

Q View related articles $\sqsubset$ 
out wandering from natural analogies, and after having compared simple bodies under every point of view which can be presented by the properties which they possess.

I shall return to the subject in another paper.

XCIII. On the Laws olserved in the Distribution of vegetable Forms. By Alexander Count Humbold't*

Botany, long confined to the simple description of the external forms of plants and their artificial classification, now presents several branches of study, which place it more on a footing with the other sciences. Such are the distribution of vegetables according to a natural method founded upon the whole part of their structure; physiology, which displays their internal organization; botanical geography, which assigns to each tribe of plants their height, limits, and climate. 'The terms alpine plants, plants of hot countries, plants of the sea-shore, are to be found in all languages, even in those of the most savage nations on the banks of the Oronoko. They prove that the attention of tnen bas been constantly fixed on the distribution of vegetables, and on their connexion with the temperature of the air, the elevation of the soil, and the nature of the ground which they inhabit. It does not require much sagacity to observe, that on the slope of the high mountains of Armenia, vegetables of a different latitude follow each in succession, like the climates, superposed as it were upon each other. This idea of Tournefort, developed by Linnæus in two interesting dissertations, (Stationes et Colonice Plantarum, nevertheless contains the first seeds of botanical geography. Menzel, the author of an unpublished Flora of $\mathrm{Ja}^{-}$ pan, strongly recommends to travellers researches as to the dis. tribution of species in the different regions of the globe. He had even pointed out the result before by the name of the Geography of Plants. This appellation was again employed, and almost at the same time, about the year 1783 , by the Abbe Giraud Soulavie, and by the celebrated author of the Studies of Nature; a work which, amid a great variety of very inaccurate ideas as to the physique of the globe, contains some profound and ingenious views as to the forms, relations, and habitudes of vegetables. Abbé Giraud Sonlavie was occupied in preference with the plants already cultivated: he has distinguished the elimates of the olive trees, the vines, and the chesnuts. He gives a vertical section of Mount Mezin, to which he has added the

\footnotetext{
* Extracted from a paper read to the French Institute, Feb. 5, 1816.
}

harcmetrical 
barometrical heights, "because," as he says, " he has a great contempt for every result taken from barometrical measurement." His Geography of the Plants in the South of France was followed by the Tentamen Histuriae geographice Vegtabilium of the learned Professor Strohmayer, published in 1800 at Gottingen in the form of a dissertation ; but this'Tentamen exhibits rather the plan of a future work, and the catalogue of authors to be consulted, than information respecting the altitudes which spontaneous plants reach in different climates. The case is the same with the very philosophical views announced by $M$. Treviranus in his Essai de Biologie; we therein fiad general considerations, but no measurements of heights, and no thermometrical indications, which are the solid bases of the geography of plants. This study has not risen to the rank of a science, until men of science have perfected both the ineasures of heights by barometrical observations, and the determination of mean temperatures; or, what is more important for the development of vegetation, the determination of the differences between the temperature of summer and winter and between that of day and night. Few branches of study have in our day marle more rapid progress; and a long time has not intervened between the first efforts and the present period, when by the united observations of a great number of travellers, we have succeeded in fixing the limits of vegetables in Lapland, the Pyrenees, the Alps, Caucasus, and the Cordilleras of America.

The vegetables which cover the vast surface of the globe present, when we study by natural classes or families, striking differences in the distribution of their forms: it is to the laws of this distribution that I have recently turned my attention. On limiting them to the countries in which the number of the species is exactly known*, and by dividing this number by that of the Glumacece $\uparrow$, the leguminous plants, the labiated, and the compound, we find numerical relations which form very regular series. We see certain forms becone more common from the equator towards the pole, like the ferns, the glumacex, the ericinex, and the rhododendrons. Other forms on the contrary increase from the poles towards the equator, and may be considered in our hemisphere as southern forms: such are the rubiacex, the malvacea, the euphorbia, the leguminous and the coraposite plants. Finally, others attain their maximum even is the temperate zone, and diminish also towards the equatos

* Lapland, France, England, \&c. according to Messrs. Wahlenberg, Buch, Ramond, Decandolle, and Sivith.

+ The Glumace contian the three families of Graminere, Cyperacea, and Jibicacce.

and 
and the poles. Such are the labiated plants, the amentacex, the cruciferæ, and the umbelliferre. Part of the se data long since struck botanical travellers, and all those who have looked into herbals. It was known that the cruciferæ and umbelliferæ disáppeared almost entirely in the plains of the torrid zone, and that none of the malvacee were found beyond the polar circle. It is the same with the geography of the plants as with meteorology. The resuits of those sciences are so simple that in all ages general ideas have been formed of them: but it is only after laborious researches, and after having collected a great number of accurate observations, that numerical results were attained, and an acquaintance with the partial modifications undergone by the law of the distribution of forms. A table which we have drawn up exhibits this law. with respect to sixteen families of plants distributed over the equatorial, temperate, and glacial zones. We there see with satisfaction mixcd with surprise, how in organic nature, the forms present constant relations under the same isothermal parallels, i. e. on curves traced by points of the globe which receive an equal quantity of heat. The grasses form in England 1-12th, in France 1-13th, in North America 1-10th, of all the phanerogamous plants. The glumacex form in Germany $1-7$ th ; in France $1-8$ th ; in North America 1-8th; in New Holland, according to the researches of Mr. Brown, 1-Sth; of the known phanerogamous plants. The composite plants increase a little in the northern part of the new continent; for, according to the new Flora of Pursch, there is between the parallels of Georgia and Boston 1-6th ; whereas in Germany we find 1-8th; and in France 1-7th, of the total number of the species with visible fructification. In the whole temperate zone, the giumacex and the composite plants form together, nearly, onefourth of the phanerogamous plants; the glumacex, the compositæ, the cruciferæ and the leguminosæ, together nearly onethird. It results from these researches that the forms of organized beings are in a mutual dependence, and that the unity of nature is such that the forms are limited, the one after the other, according to constant laws easy of determination. When we know upon any point of the globe the number of species presented by one of the great families of the glumacex, the composite, the cruciferous, or the leguminous plants, we may estimate with considerable probability both the total number of the phanerogamous plants, and the number of species which compose the other vegetable families. It is thus that, by knowing under the temperate zone the number of the cyperaceæ or composite plants, we may guess at that of the gramineous or leguminous plants. 
The number of vegetable species described by botanists, or existing in European herbals, extends to 44000 , of which 6000 are agamous. In this number we had already included 3000 new phanerogamous species enumerated by $M$. Bonpland and myself. France, according to M. Decandolle, possesses 3645 phanerogamous plants, of which 460 are glumacex, $490 \mathrm{com}-$ posite, and 230 leguminous, \&c. In Lapland there are only 497 phanerogamous plants; among which are 124 glumacex, 55 composite, 14 leguminous, 23 amentaceous, \&c. See my Essay on the Geography of Plants published in 1806 , and of which I am preparing a new edition.

In order to account for the differences which exist sometimes between the relations exhibited by Germany, North America, and France, we must take into consideration the more or less temperate climates of those regious. France extends from $422_{2}^{\circ}$ to $51^{\circ}$ of latitude. On this extent the mean annual heat is $16^{\circ} 7^{\prime}$ to $1 i^{\circ}$ : the mean heats of the summer months are $24^{\circ}$ to $19^{\circ}$. Germany, comprised between $46^{\circ}$ and $54^{\circ}$ of latitude, presents at its extremities mean annual temperatures of $12^{\prime \prime} 5^{\prime}$ and $8^{\circ} 5^{\prime}$. The mean heats of the summer months there are $21^{\circ}$ and $18^{\circ}$. North America, in its immense extent, presents the most varied climates. Mr. Pursch has made us acquainted with 2000 phanerogamous plants which grow between the parallels of $35^{\circ}$ and $44^{\circ}$; consequently under mean annual temperatures of $16^{\circ}$ and $7^{\circ}$. The Flora of North America is a mixture of several Floras. The southern regions give it an abundance of malvacex and composite plants; the northern regions, colder than Europe under the same parallel, furnish to this Flora abundance of rhododendrons, amentacex, and coniferæ. The caryophyllex, the umbelliferæ, and the cruciferæ are in general more rare in North America than in the temperate zone of the old continent*.

These constant relations observed on the surface of the globe, in the plains from the equator to the pole, are again traced in the midst of perpetual snows on the summits of mountains. We may admit, in general, that on the cordilleras of the torrid zone the boreal forms become more frequent. It is thus that we see prevail at Quito on the summit of the Andes, the ericineæ, the

* For the sake of those who are not much conversant in descriptive botany, we shall here enumerate the plants which serve as a type to the forms or principal families: Glumaced, rushes, tares; orchidea, orchis, satyrion, vanilla; labiata, sage ; ericinea, broom; compositce, coltsfoot, tussiłago; onbiace, madder, quinquina; umbellifere, fennel; crucifera, radish, cabbage; malyacea, cotton; leguminosa, furze, truffles, sensitive plaxt; euphorbiacee, milky thistle; amentacee, willow, ouk; conifere, pine, yew, juniper.

Vol, 47. No. 218, June 1816. 
rhododendrons, and the gramineous plants. On the contrary, the labiatæ, the rubiaceæ, the malvaceæ, and the euphorbiace then become as rare as thay are in Lapland. But this analogy is not supported in the ferns and the composite plants. Tho latter abound on the Andes, whereas the former gradually disappear when they rise above 1800 fathoms in height. Thus the cimate of the Andes resembles, that of northern Europe only with respect to the mean temperature of the year. The repartivion of heat into the different seasons is entirely difierent, and powerfully infuences the phænomena of vegetation. In general, the forms which prevail among the Alpine plints are, according to my researches, UNDER THE TORRID ZONE, the graminece (ægopogon, podosæmum, deyeuxia, avena) ; the composita (culcitium, espeletia, aster, baccharis); and the caryophyllece (arenaria, stellaria). UNDER THE TEMPERATE zONE, the compositce (senecio, leontodon, aster); the caryophyllece (cerastium, cherleria, silene); and the cruciferce (draba, lepidium). UNDER THE FROZEN ZONE, the caryophyllece (stellaria, alsine); the ericinea (andromeda) and the ranunulacece.

These researches into the law of the distribution of forms, naturally lead to the question whether there exist plants common to both continents? a question which inspires the more interest, as it belongs to one of the most important problems in Zoonomia. It has been long known, and it is one of the most interesting results from the geography of animals, that no quadruped, no terrestrial bird, and, as appears from the researches of M. Latreille, almost no insect, is common to the equatorial regions of the two worlds. M. Cuvier is convinced by precise inquiries that this rule applies even to reptiles. He has ascertained that the true boa constrictor is peculiar to America, and that the boas of the old continent were pytons. As to the regions beyond the tropics, Buffon has multiplied beyond measure the number of the animals common to America, to Europe, and the north of Asia. We are assured that the bison, the stag, and the goat of America, the rabbit and the musk rat, the bear, \&c. \&e. are species entirely different from those of Europe, although Buffon had affirmed the contrary. There remain only the glutton, the wolf, the white bear, the red fox, perhaps also the elau, which have not characters sufficient to entitle them to be specific. Among the plants, we must distinguish between the agamæ and the cotyledonex; and by considering the latter between the monocotylodens and the dicotyledons. There remains no doubt that many of the mosses and lichens are to be found at once in equinoctial America and in Europe : our herbals show this. But the case is not the same with the vascular agama as with the agame of a cellular texture. The ferns and the lyeoporiacere 
do not follow the same laws with the mosses and the lichens. The former, in particular, exhibit very few species universally to be found; and the examples cited are frequently doubtful. As to the phanerogamous plants (with the exception of the rhizophora, the avicennia, and some other littoral plants), the law of Buffon seems to be exact with respect to the species furnished with two cotyledons. It is absolutely false, although it has been often affirmed, that the ridges of the cordilleras of Peru, the climate of which has some analogy with the climate of France or Sweden, produce similar plants. The oaks, the pines, the yews, the raunuculi, the rose-trees, the alchemilla, the valerians, the stellaria, the draba of the Peruvian and Mexican Andes, have nearly the same physiognomy with the species of the same genera of North America, Siberia, or Furope. But all these alpine plants of the Cordilleras, without excepting one among three or four thousand which we have examined, differ specifically from the analogous species of the temperate zone of the old continent. In general, in that part of America situated between the tropics, the monocotyledontal plants alone, and among the latter almost solely the cyperaceæ and the gramineæ, are common to the two worlds. These two families form an exception to the general law which we are here examining,-a law which is so important for the history of the catastrophes of our planet, and according to which the organized beings of the equinoctial regions differ essentially in the two continents. I have given in my Prolegomena a precise catalogue of those monocotyledontal plants common to the shores of the Oronoko, Germany, and the East Indies. Their number does not exceed 20 or 24 species, among which it is sufficient to cite the cyperus mucronatus, c. hydra, hypælyptum argenteum, poa eragrostis, andropogon, allioni, \&c.

Iu North America placed beyond the tropics, we find nearly one-seventh of monocotyledontal and dicotyledontal plants common to the two continents. Of 2900 phanerogamous species collected in the New Flora of Pursch, 390 are European. It is true that we may hazard some doubts, as well with respect to the number of the plants which have accompanied Europeans from one hemisphere to the other, as upon those which, when better examined, will be recognised subsequently as new species: but it is impossible that this stite of uncertainty should extend to all; and it is to be presumed that, even after a careful examination, the number of the species common to the temperate zones of the two worlds will still remain very considerably analogous. Mr. Brown recently undertook sone researches on the plants of New Holland. A twenty-eighth part of all the monocotyledons !itherto found in the anstral continent are common Fi 2 


\section{Laws olserved in the Distrilution of vegetalle Forms.}

to it with England, France, and Germany. Among the dicotyledons the ratio is only $l$ in 200 ; which proves once more how, in the two hemispheres, the grasses and the cyperacex are the most diffused, on account of the extreme flexibility of their organization. It would be desirous that learned zoologists should endeavour to examine the analogous numerical ratios presented by the distribution of the different families of animals on the gilobe.

In the austral hemisphere the vegetable forms of the torrid zone advance more towards the pole than in the boreal hemisphere. The fern-trees in Asia and America are rarely to be found beyond the tropic of Cancer; whereas in the austral part of our globe the Dicksonia antarctica, the trunk of which is six metres in height, pushes its migrations as far as Van Diemen's Land under the latitude of $42^{\circ}$ : it has even been found in New Zealand, in Dusky Gulph, under the parallel of Lyons.

Other forms not less majestic, and which were thought to belong exclusively to the equinoctial Flora, the parasite orchideæ (epidendra, deudrobia) are found mixed with the arborescent ferus far beyond the tropic of Capricorn, in the centre of the austral temperate zone. These phænomena of the geography of plants prove how vague is what has been generally said of the great diminution of temperature in the southern henisphere, without distinguishing between the parallels more or less near the pole, and without any regard to the division of heat among the different seasons of the year. Those regions towards which the equinoctial forms extend, possess, on account of the immensity of the seas which surround them, a true island climate. From the tropic of Capricorn to the parallel of $34^{\circ}$, and perhaps still further, the mean heats of the vear (i.e. the quantity of heat received by any given point of the globe) do not differ considerably in the two hemispheres. On casting our eyes over the three continents, New Holland, Africa, and America, we find that the mean anmual temperature of Port Jackson (lat. $33^{\circ} 5 \mathrm{I}^{\prime}$ ) is $19^{\circ} 3^{\prime}$ of the centigrade thermometer : that of the Cape of Good Hope (lat. 33 $55^{\prime}$ ) $19^{\circ} 4^{\prime}$; that of the town of Buenos Ayres (lat. $34^{\circ} 36^{\prime}$ ) $19^{\circ} 7^{\prime}$. We may be surprised at this great equality in the distribution of heat by the $34^{\circ}$ of austral latitude. Meteorological observations, still more precise, prove that in the borcal hemisphere, under this very parallel of $34^{\circ}$, we find a mean temperature of $19^{\circ} 8^{\prime}$. On advancing towards the antarcic pole, perhaps even to the parallel of $57^{\circ}$, the temperatures of the two hemispheres differ less in winter than summer. The Malouine Islands, situated in $5 \mathrm{I}^{\circ}$ and a half of south latitude, have less intense cold in winter than is experienced at London. The mean temperature of Van Diemen's Land seems to be $10^{\circ}$; it freezes 
during winter, but not so much as to destroy the fern-trees and the parasite orchidex. In the adjoining seas Capt. Cook, in $42^{\circ}$ of austral latitude, did not see the thermometer fall below $+6^{\circ}, 6$ in the midst of winter (July). To these very mild winters, summers succeed remarkable for an extraordinary coolness. At the southern extremity of New Holland (lat. $42^{\circ} 41^{\prime}$ ) the temperature of the air rarely rises in the midst of summer at noon-day higher than $12^{\circ}$ or $14^{\circ}$; and in Patagonia, as in the adjoining ocean (lat. $48^{3}-58^{3}$ ), the mean heat of the warmest month is only $7^{\circ}-8^{\circ}$; whereas in the boreal hemisphere at Petersburg and Umeo (lat. $59^{\circ} .56^{\prime}$ and $63^{\circ} 50^{\prime}$ ) this heat exceeds 17-19. It is this mild temperature of the islands, which the southem countries enjoy between $30^{\circ}$ and $40^{\circ}$ of latiturle, which permits the vegetable forms to pass beyond the tropic of Capricorn. They embellish a great part of the temperate zone; and the genera which the inhabitant of the northern hemisphere regards as exclusively belonging to the tropical climates, present numerous species between the parallels of $35^{\circ}$ and $38^{\circ}$ of south latitude.

XCIV. Notices respeciing New Books.

Essays on Insanity, Hypochondriasis, and other Nervous Affections. By John ReID, M.D. Memler of the Royal Cullege of Physicians, London; and late Physician to the Hinslury Dispensary. pp. 272. 8vo. Longman and Co.

OUr readers will fund in the above work a rational and philosophical view of the most distressing of all the aflictions to which human nature is subject. The treatment recommended by $\mathrm{Dr}_{\mathrm{r}}$. Reid is that of gentleness and lindress on all occasions, and coincides in all its bearings with the views which have been taken of this distressing subject, by those enlightened legislators and other friends of humanity who have of late directed the public attention to the condition of those afflicted with mental derangenent.

Dr. Reid's ideas of modern lunatic asylums are precisely those which now generally prevail, and by the adoption of which much human misery will in all probability be in future spared; and to his credit be it remembered, that the hints which we are abont to subjoin were thrown out in another form several years ago by the enlightened author, and so far he may claim the merit of originality. We now present our readers with the doctor's description of those charnel houses of the human intellect called Lunatic Asylums, as a specimen not only of his philosophical. 